\section{(D) Check for updates}

Cite this: DOI: 10.1039/d0dt03326j

\title{
2-Pyridone-stabilized iridium silylene/silyl complexes: structure and QTAIM analysis $\uparrow$
}

\author{
Jefferson Guzmán, ${ }^{a}$ Ana M. Bernal, ${ }^{a}$ Pilar García-Orduña, ${ }^{a}$ Fernando J. Lahoz, (D) a \\ Víctor Polo (D) *b and Francisco J. Fernández-Alvarez (D) *a
}

\begin{abstract}
Iridium (III) complexes of the general formula $\left[\mathrm{Ir}(\mathrm{X})\left(\mathrm{K}^{2}-\mathrm{NSi}^{\mathrm{iPr}}\right)_{2}\right]$ ( $\left(\mathrm{NSi} \mathrm{Pr}^{\mathrm{iPr}}=\right.$ (4-methyl-pyridine-2-yloxy)diisopropylsilyl; $\mathrm{X}=\mathrm{Cl}, 3 ; \mathrm{CF}_{3} \mathrm{SO}_{3}, 5 ; \mathrm{CF}_{3} \mathrm{CO}_{2}, 6$ ) have been prepared and fully characterized, including $\mathrm{X}$-ray diffraction studies and theoretical calculations. The presence of isopropyl substituents at the silicon atom favours the monomeric structure found in complexes $\mathbf{3}$ and $\mathbf{5}$. The short $\mathrm{Ir}-\mathrm{Si}$ bond distances

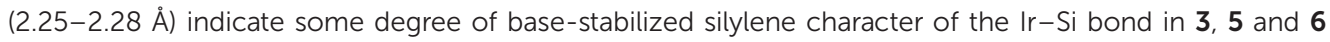
assisted by the 2-pyridone moiety. However, the shortening of these Ir-Si bonds might be a consequence of the constrained 2-pyridone geometry, and consequently the silyl character of these bonds can not be excluded. A DFT theoretical study on the nature of the Ir-Si bonds has been performed for complex $\mathbf{3}$ as well as for four other iridium complexes finding representative examples of different bonding situations between Ir and Si atoms: silylene, base-assisted silylene (both with an anionic base and with a neutral base), and silyl bonds, using the topological properties of the electron charge density. The results of these studies show that the $\mathrm{Ir}-\mathrm{Si}$ bonds in $\mathrm{Ir}-\mathrm{NS} \mathrm{i}^{\mathrm{iPr} 2}$ complexes can be considered as an intermediate between the base-stabilized silylene and silyl cases, and therefore they have been proposed as 2-pyridone-stabilized iridium silylene/silyl bonds.
\end{abstract}

Received 24th September 2020 Accepted 18th November 2020

DOI: $10.1039 / \mathrm{d} 0 \mathrm{dt} 03326 \mathrm{j}$

rsc.li/dalton
In this regard, transition-metal complexes with monoanionic $\kappa^{2}$-pyridine-2-yloxy-silyl ligands, ${ }^{8}$ which exhibit short metal-Si bond distances, ${ }^{9}$ have been proposed as examples of base-stabilized metal-silylene species (I; Fig. 2). ${ }^{10-12}$ The Ir-Si bond in iridium(III) complexes with pyridine-2-yloxy-silyl ligands, recently reported by our group, may be viewed as an example of a base-assisted metal-silylene bond. ${ }^{13,14}$ The short Ir-Si bond lengths found for $\mathrm{Ir}-\left(\mathrm{NSi}^{\mathrm{R} 2}\right)\left(\mathrm{R}=\mathrm{Me},{ }^{13}{ }^{t} \mathrm{Bu}^{14}\right)$ species, in the 2.25-2.29 A range, suggest a base-stabilized silylene character for these Ir-Si bonds, and therefore they could be represented as 2-pyridone-stabilized iridium-silylene bonds (I in Fig. 2). However, in our opinion, it cannot be ruled out that the shortening of these metal-Si bond lengths might be a consequence of the constrained 2-pyridone geometry, since this moiety acts as a bridge between the transition-metal and

\footnotetext{
${ }^{a}$ Departamento de Química Inorgánica-Instituto de Síntesis Química y Catálisis Homogénea (ISQCH), Universidad de Zaragoza-CSIC, Facultad de Ciencias, 50009 Zaragoza, Spain. E-mail: paco@unizar.es

${ }^{b}$ Departamento de Química Física-Instituto de Biocomputación y Física de Sistemas Complejos (BIFI), Universidad de Zaragoza, Facultad de Ciencias, 50009 Zaragoza, Spain.E-mail:vipolo@unizar.es

$\dagger$ Electronic supplementary information (ESI) available. CCDC 1989980-1989982. For ESI and crystallographic data in CIF or other electronic format see DOI: 10.1039/d0dt03326j
}

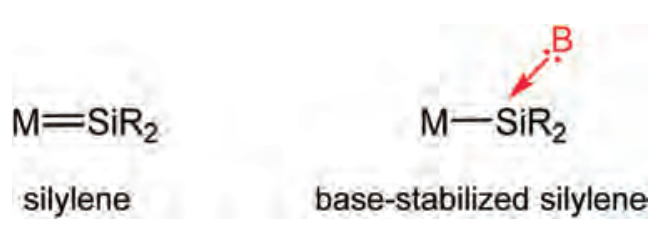

Fig. 1 Metal-silylene versus base-stabilized metal-silylene species ( $M=$ transition metal complexes; $B=$ Lewis base). 


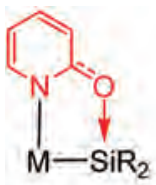

I

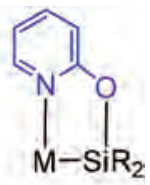

II
Fig. 2 2-Pyridone-stabilized metal-silylene (I) versus 2-pyridonestabilized metal-silyl (II) canonical forms in $\mathrm{M}-\left(\kappa^{2}-\mathrm{NSi}^{\mathrm{R} 2}\right)$ complexes ( $M=$ transition metal).

the silicon atom; thus, the metal-silyl character of these bonds should not be excluded (II in Fig. 2).

The chemical bond in some transition metal-silylene complexes have been theoretically studied using different methodologies such as calculations of bond energies, quantum theory of atoms-in-molecules (QTAIM) and energy decomposition analysis (EDA), among others. ${ }^{15}$ Conversely, the nature of the iridium-silylene chemical bond has been relatively unexplored from a theoretical point of view. Therefore, any advance in knowledge of these Ir-Si interactions has an intrinsic interest. While some metal-silylene bonds can be stabilized by metal $\pi$ back-donation to the silylene, in the so-called base-assisted metal-silylene bond the empty $\mathrm{p}_{z}$ orbital of the silylene ligand is stabilized by a donor group (neutral or anionic).

Herein, we extend our studies on the chemistry of iridium (III) complexes with pyridine-2-yloxy-silyl ligands ${ }^{13,14}$ to a new ligand (4-methyl-pyridine-2-yloxy)diisopropylsilyl ( $\left.\mathrm{NSi}^{\mathrm{iPr} 2}\right)$. In contrast to the previously studied ligand, (4-methyl-pyridine-2yloxy)dimethylsilyl $\left(\mathrm{NSi}^{\mathrm{Me} 2}\right),{ }^{13,16}$ this ligand favours monomeric structures. To shed light on the nature of the Ir-Si bonds between the metal and the silicon atoms in $\mathrm{Ir}-\mathrm{NSi}^{\mathrm{P} \text { r2 }}$ species, a theoretical analysis using the topological properties of the electronic density charge has been performed. For the sake of completeness, we have also investigated four related iridium(III) complexes representative of Ir-silylene, base-stabilized Ir-silylene and Ir-silyl bond cases.

\section{Results and discussion}

\section{Synthesis of iridium complexes with the monoanionic bidentate (4-methylpyridine-2-yloxy)diisopropylsilyl ligand}

Three methodologies for the synthesis of metal complexes with monoanionic bidentate pyridine-2-yloxy-silyl ligands have been commonly employed (Scheme 1): (i) the reaction of silyl transition metal complexes with pyridine-2-yloxy salts, ${ }^{10}$ (ii) the reaction of silyl transition metal complexes with 2-hydroxypyridine in presence of a Lewis base ${ }^{11}$ and (iii) the pyridinedirected oxidative addition of the $\mathrm{Si}-\mathrm{H}$ bond to low valent metal complexes. ${ }^{13,14,16}$

Iridium-NSi ${ }^{\mathrm{R} 2}$ ( $\mathrm{R}=$ alkyl) complexes have been prepared so far, following path iii in Scheme 1, by reaction of the corresponding pyridine-2-yloxy-silane derivative with $\left[\operatorname{Ir}(\mu-\mathrm{Cl})(\mathrm{coe})_{2}\right]_{2}$ (coe = cis-cyclooctene). The bulkyness of the silicon subtituents influences the nature of the reaction products (Scheme 2). i)
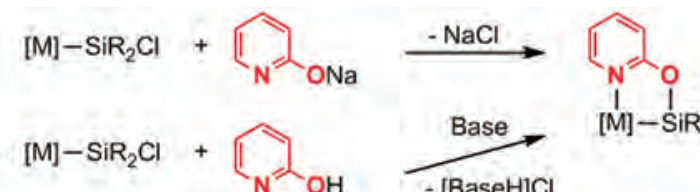

ii)
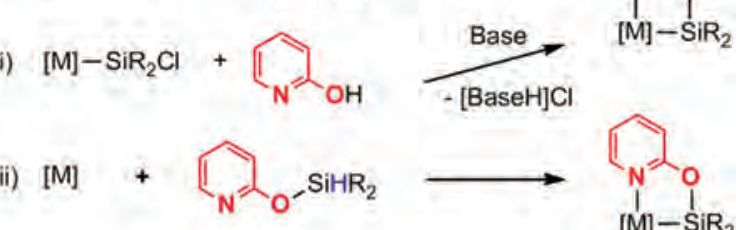

iii)

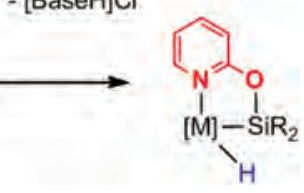

Scheme 1 Examples of synthesis of $\mathrm{M}-\left(\kappa^{2}-\mathrm{NSi}^{\mathrm{R} 2}\right)$ complexes ( $M=$ transition metal complex).

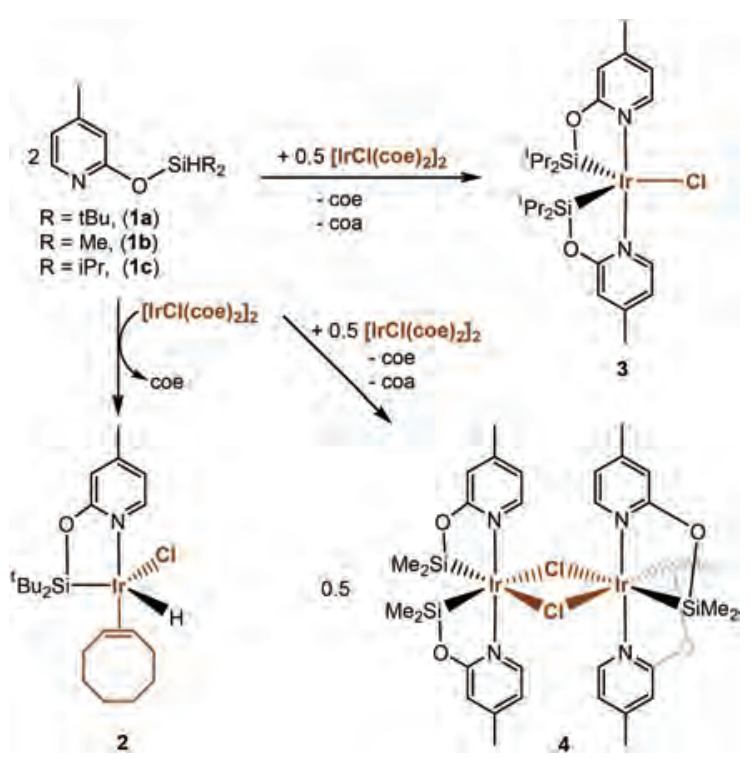

Scheme 2 Reactivity of the functionalized silanes $\mathrm{NSi}^{\mathrm{R} 2}-\mathrm{H}\left(\mathrm{R}={ }^{t} \mathrm{Bu}, 1 \mathrm{a}\right.$; $\mathrm{Me}, 1 \mathrm{~b}$; $\operatorname{Pr} 1 \mathrm{c})$ with $\left[\operatorname{Ir}(\mu-\mathrm{Cl})(\mathrm{coe})_{2}\right]_{2}$.

Thus, while the reaction of two equivalents of $\mathrm{NSi}^{t \mathrm{Bu} 2}-\mathrm{H}(\mathbf{1 a})$ with $\left[\operatorname{Ir}(\mu-\mathrm{Cl})(\mathrm{coe})_{2}\right]_{2}(1: 1$ ratio $\mathbf{1 a}: \operatorname{Ir})$ in $\mathrm{CH}_{2} \mathrm{Cl}_{2}$ selectively leads to the mononuclear complex $\left[\operatorname{Ir}(\mathrm{H})(\mathrm{Cl})\left(\kappa^{2}-\mathrm{NSi}^{t \mathrm{tu} 2}\right)(\mathrm{coe})\right]$ $(2){ }^{14}$ using $\mathrm{NSi}^{\mathrm{R} 2}-\mathrm{H}\left(\mathrm{R}=\mathrm{Me}, \mathbf{1 b} ;{ }^{13}\right.$ iPr, $\left.\mathbf{1 c}\right)$ as ligand precursors, under the same ratio, mixtures of unidentified complexes, some of them containing $\mathrm{Ir}-\mathrm{H}$ bonds were obtained (Scheme 2). On the other hand, the reaction between four equivalents of $\mathbf{1 c}$ and $\left[\operatorname{Ir}(\mu-\mathrm{Cl})(\mathrm{coe})_{2}\right]_{2}(2: 1$ ratio $1 \mathbf{c}:$ Ir) yields the iridium(III) species $\left[\operatorname{Ir}(\mathrm{Cl})\left(\kappa^{2}-\mathrm{NSi}^{\mathrm{iPr} 2}\right)_{2}\right]$ (3), which was isolated in $70 \%$ yield as a white solid. Complex $\mathbf{3}$, as discussed later, possesses a monomeric structure in the solid-state differently to the dinuclear species $\left[\operatorname{Ir}(\mu-\mathrm{Cl})\left(\kappa^{2}-\mathrm{NSi}^{\mathrm{Me} 2}\right)_{2}\right]_{2}(4) .{ }^{13 a}$ This could be explained considering the higher steric hindrance of the $\mathrm{NSi}^{\mathrm{iPr} 2}$ ligand in comparison with $\mathrm{NSi}^{\mathrm{Me} 2}$ (Scheme 2). In this regard, it has been observed that complex 2, with a $\mathrm{NSi}^{t \mathrm{Bu} 2}$ ligand, does not react with one additional equivalent of $\mathrm{NSi}^{\mathrm{iBu} 2}-\mathrm{H}(\mathbf{1 a})$, which could be due to the steric hindrance of the ${ }^{t} \mathrm{Bu}$ substituents at the silicon atom.

The reaction of 3 with one equivalent of $\mathrm{AgCF}_{3} \mathrm{CO}_{2}$ or $\mathrm{AgCF}_{3} \mathrm{SO}_{3}$ at room temperature gives the corresponding deriva- 


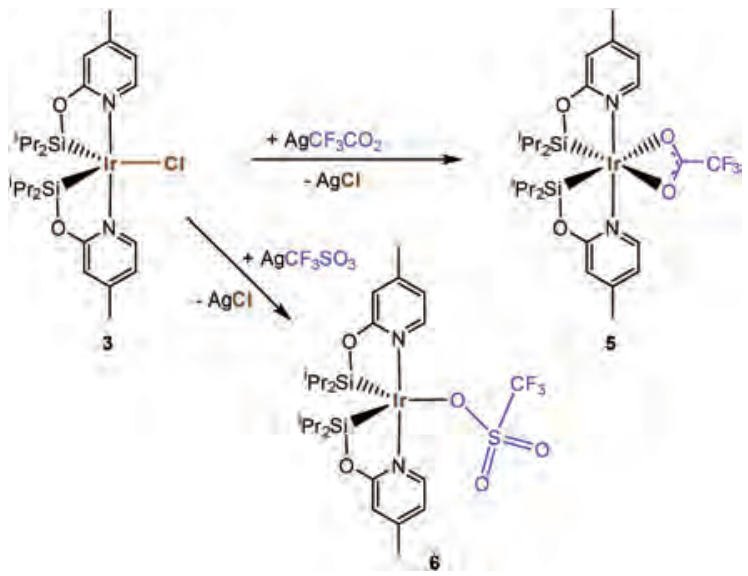

Scheme 3 Synthesis of the $\mathrm{Ir}-\left(\mathrm{\kappa}^{2}-\mathrm{NS} \mathrm{i}^{\mathrm{PP} 2}\right)$ derivatives 5 and 6 .

tive $\left[\operatorname{Ir}\left(\kappa^{2}-\mathrm{CF}_{3} \mathrm{CO}_{2}\right)\left(\kappa^{2}-\mathrm{NSi}^{\mathrm{iPr} 2}\right)_{2}\right](5)$ or $\left[\mathrm{Ir}\left(\mathrm{CF}_{3} \mathrm{SO}_{3}\right)\left(\kappa^{2}-\mathrm{NSi}^{\mathrm{iPr} 2}\right)_{2}\right]$ (6) (Scheme 3). Complexes $\mathbf{5}$ and $\mathbf{6}$ were isolated as yellow solids in $76 \%$ and $67 \%$ yield, respectively. Their ${ }^{1} \mathrm{H},{ }^{13} \mathrm{C}\left\{{ }^{1} \mathrm{H}\right\}$ and ${ }^{19} \mathrm{~F}$ NMR spectra agree with the structure determined for such species (vide infra) and represented in Scheme 3. The ${ }^{1} \mathrm{H}$ and ${ }^{13} \mathrm{C}\left\{{ }^{1} \mathrm{H}\right\}$ NMR spectra of complexes $3\left(\mathrm{CD}_{2} \mathrm{Cl}_{2}\right), 5$ and $\mathbf{6}$ $\left(\mathrm{C}_{6} \mathrm{D}_{6}\right)$ are in agreement with the high symmetry of these species (Experimental section). Thus, their ${ }^{1} \mathrm{H}$ NMR spectra show three multiplet resonances centered at $\delta 8.81,6.71$ and $6.63 \mathrm{ppm}(3) ; \delta 8.41,6.40$ and $5.82 \mathrm{ppm}(5)$ and $\delta 8.95,6.33$ and $6.01 \mathrm{ppm}(6)$ in the aromatic region and one singlet at $\delta$ 2.27 (3), 1.51 (5) and $1.48 \mathrm{ppm}$ (6) due to the methyl substituents of the pyridinic rings, which confirms that in such compunds the two $\kappa^{2}-\mathrm{NSi}^{\mathrm{iPr} 2}$ ligands are equivalent in solution. Moreover, ${ }^{29} \mathrm{Si}\left\{{ }^{1} \mathrm{H}\right\}$ NMR spectra of complexes 3, 5 and $\mathbf{6}$ show a singlet resonance at $\delta 50.5,42.2$ and $44.5 \mathrm{ppm}$, respectively, which is low field shifted in comparison with the resonance observed for the parent silane 1c $(\delta 12.4 \mathrm{ppm})$. These values compare well with those reported by Tilley, Bergman and Klei for cationic iridium(III)-silylene complexes [IrCp* Me $\left\{\mathrm{SiMe}_{2}\right.$ (pyridine) $\left.\}\left(\mathrm{PMe}_{3}\right)\right][\mathrm{A}] \quad\left(\mathrm{A}=\mathrm{B}\left(\mathrm{C}_{6} \mathrm{~F}_{5}\right)_{4}{ }^{-}\right.$or $\mathrm{CF}_{3} \mathrm{SO}_{3}{ }^{-}$; $\delta 49.0 \mathrm{ppm}),{ }^{17}$ and further support the base-stabilized silylene character of the Ir-Si bond in the aforementioned complexes.

The high resolution mass spectra (HR-MS; $\mathrm{ESI}^{+}$) of compounds 3,5 and $\mathbf{6}$ present a similar pattern. In all the cases, a major peak centered at $m / z=637.2260\left(\mathrm{M}^{+}-\mathrm{Cl} ; 3\right), 637.2250$ $\left(\mathrm{M}^{+}-\mathrm{CF}_{3} \mathrm{CO}_{2} ; 5\right)$ or $637.2245\left(\mathrm{M}^{+}-\mathrm{CF}_{3} \mathrm{SO}_{3} ; 6\right)$, has been observed. This peak has been assigned to the cationic fragment $\left[\operatorname{Ir}\left(\kappa^{2}-\mathrm{NSi}^{\mathrm{iPr} 2}\right)_{2}\right]^{+}$(calc. $\left.m / z=637.2258\right)$ and confirms the strength of the Ir-Si bond in such species.

\section{Determination of the solid-state structure of complexes 3,5 and 6}

The solid-state structure of complexes 3, 5 and $\mathbf{6}$ was established by single crystal X-ray diffraction studies. Complex 3 crystallizes with two crystallographically independent, but chemically identical molecules in the unit cell. In both molecules the metal atom exhibits a slightly distorted bipyramidal trigonal geometry, with the equatorial plane defined by silicon

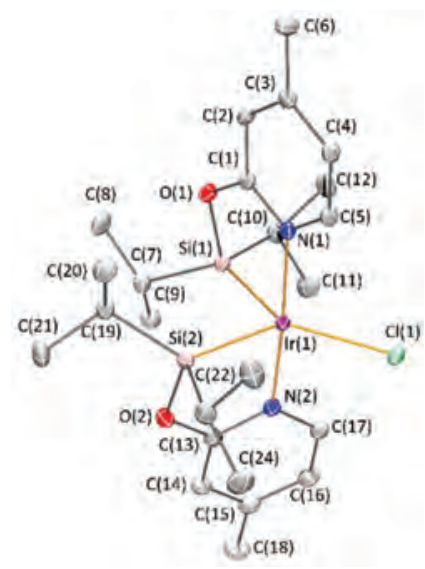

Fig. 3 Molecular structure of compound 3. For clarity, only one of the two independent molecules is represented, and hydrogen atoms have been omitted.

atoms and the chloro ligand while the apical positions are occupied by nitrogen atoms (Fig. 3).

The molecular structure of 3 shows the nitrogen atoms of the pyridinic rings with a small deviation from an ideal transdisposition ( $\mathrm{N}-\mathrm{Ir}-\mathrm{N}$ angles are found to be $175.56(8)^{\circ}$ and $\left.175.28(8)^{\circ}\right)$. In the equatorial plane, the Si-Ir-Si angles are very narrow $\left(87.96(2)^{\circ}\right.$ and $\left.87.31(2)^{\circ}\right)$, as may be expected between two strong trans-influencing ligands, with a value smaller than that found in the octahedral iridium complex [IrH $\left.\left(\mathrm{SiMe}_{2} \mathrm{Cl}\right)_{2}(\mathrm{CO})(\mathrm{dppe})\right]\left(90.06(8)^{\circ}\right.$, dppe $=1$,2-bis(diphenylphosphino)ethane), ${ }^{18}$ and close to that observed in the distorted bipyramidal iridium(III) complex $\left[\operatorname{IrCl}\left(\kappa^{2}-\mathrm{PSi}\right)_{2}\right] \quad\left(86.3(3)^{\circ}\right.$, $\mathrm{PSi}=\mathrm{PPh}_{2} \mathrm{CH}_{2} \mathrm{CH}_{2} \mathrm{SiMe}_{2}-{ }^{19}{ }^{19}$ The Ir-Si bond lengths, 2.2499(7) and 2.2700(7) $\AA$, are in the range of distances reported for base-stabilized Ir-silylene complexes. ${ }^{4-7}$ It is noteworthy that only in one of the independent molecules of complex 3, both Ir-Si bond lengths and Si-Ir-Cl bond angles are found to be similar (Table 1: complex 3, molecule 2). On the contrary, an asymmetry is observed in the related molecule 1 , where a longer Ir-Si bond length is observed trans located to chlorine atom (Ir(1)-Si(1): 2.2700(7); $\operatorname{Ir}(1)-\operatorname{Si}(2): 2.2499(7) \AA)$ and a marked difference is observed between Si-Ir-Cl angles (125.97 (2) and $\left.146.07(2)^{\circ}\right)$. This observed asymmetry is probably due to the involvement of only one chlorine atom $(\mathrm{Cl}(1)$, of molecule 1) in intermolecular $\mathrm{C}-\mathrm{H} \cdots \mathrm{Cl}$ interactions $\left(\mathrm{C}\left(46^{\prime}\right)-\mathrm{H}\left(46^{\prime}\right)\right.$ : $0.95 \AA$; $\mathrm{C}\left(46^{\prime}\right) \cdots \mathrm{Cl}(1): 3.645(1) \AA ; \mathrm{C}\left(46^{\prime}\right)-\mathrm{H}\left(46^{\prime}\right) \cdots \mathrm{Cl}(1): 159.0^{\circ}$, for a graphical representation see the Fig. S23†). This has also an effect on the Ir-Cl bond length, which is elongated in molecule 1 (2.4335(6) vs. 2.4151(7) ̊).

The metal atom in $\mathbf{5}$ exhibits a distorted octahedral geometry, with oxygen and silicon atoms in an equatorial plane, and apical positions occupied by nitrogen atoms (Fig. 4). The iridium-silicon bond lengths in 5, 2.2668(11) and 2.2702(10) $\AA$, compare well with those found in 3 . The Ir-O bond lengths, 2.413(3) and 2.421(3) $\AA$, are in the same range than those reported for the iridium(III)-NSi ${ }^{\mathrm{Me} 2}$ species $\left[\operatorname{Ir}\left(\kappa^{2}-\mathrm{CF}_{3} \mathrm{CO}_{2}\right)\left(\kappa^{2}-\right.\right.$ $\left.\left.\mathrm{NSi}^{\mathrm{Me} 2}\right)_{2}\right],{ }^{13 a}$ and are clearly longer than the values found in 
Table 1 Bond lengths $(\AA)$ and angles for metal coordination in complex 3, 5 and 6

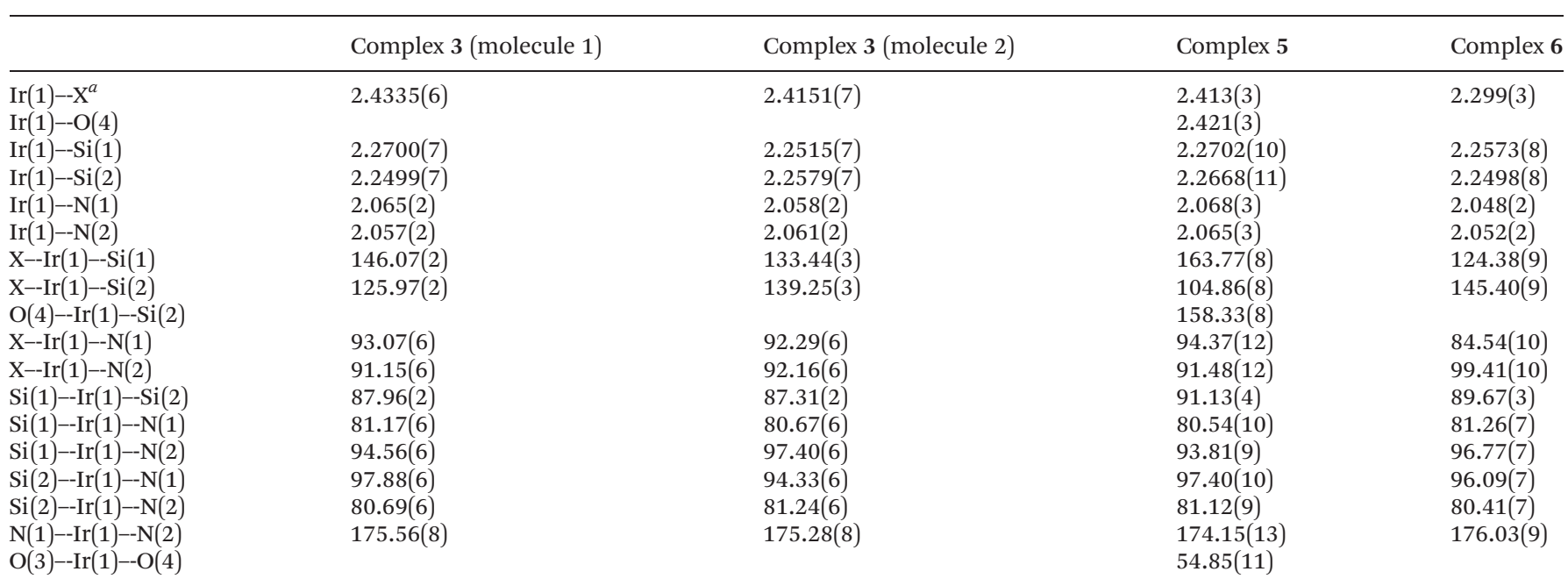

${ }^{a} \mathrm{X}$ represents chloro ligand in complex $\mathbf{3}, \mathrm{O}(3)$ and $\mathrm{O}(3 \mathrm{~A})$ in complex 5 and $\mathbf{6}$, respectively.

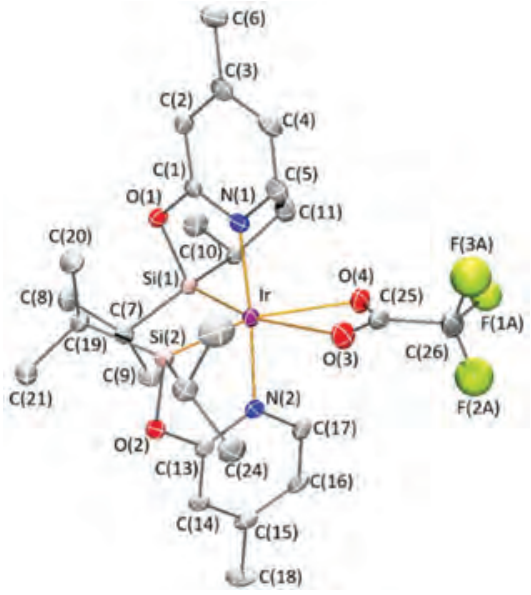

Fig. 4 Molecular structure of $\left[\operatorname{lr}\left(\mathrm{CF}_{3} \mathrm{CO}_{2}\right)\left(\kappa^{2}-\mathrm{NSi}^{\mathrm{iPr} 2}\right)_{2}\right]$ (5). For clarity, hydrogen atoms and the minor component of the disordered fragment have been omitted.

iridium-acetate-Phebox (Phebox = 3,5-dimethylphenyl-2,6-bis (oxazolinyl)) derivatives (around $2.30 \AA$ ). ${ }^{20}$ This latter fact has been attributed to the strong trans influence of the silyl groups, weakening the coordination of the trifluoroacetate fragment. ${ }^{13 a}$

Analogously to 3, complex 6 is a pentacoordinated mononuclear species, which differs from the dinuclear structures found for the related $\mathrm{Ir}-\mathrm{NSi}^{\mathrm{Me} 2}$ chloro ${ }^{13 a}$ and triflate ${ }^{13 b}$ derivatives. Complex 6 exhibits a bipyramidal trigonal metal coordination (Fig. 5), with the geometrical parameters comparable to those observed in complex $\mathbf{3}$, as is summarized in Table 1 . The iridium-silicon bond lengths in 6, 2.2498(8) and 2.2573(8) $\AA$, are shorter than those found in $\mathbf{5}$.

The coordination features of $\mathrm{NSi}^{\mathrm{R} 2}$ ligands in $\mathrm{Ir}-\left(\mathrm{\kappa}^{2}-\right.$ $\left.\mathrm{NSi}^{\mathrm{Me} 2}\right)^{13}$ and $\mathrm{Ir}-\left(\kappa^{2}-\mathrm{NSi}^{\mathrm{iPr} 2}\right)$ species are very similar $(\mathrm{ESI} \dagger)$. The

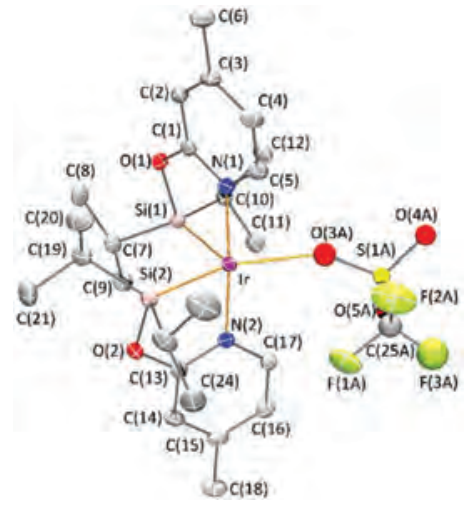

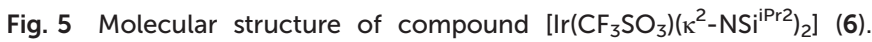
For clarity hydrogen atoms and the minor component of the disordered fragment have been omitted.

$\kappa^{2}$-coordination of the pyridine-2-yloxy-silyl ligands leads to the formation of two five-membered iridacycles $\mathrm{Ir}-\mathrm{Si}-\mathrm{O}-\mathrm{C}-\mathrm{N}$, with close puckering amplitudes (around $0.2288 \AA$ ) and phase angles characteristics of $\mathrm{E}_{2}$ and ${ }^{1} \mathrm{~T}_{2}$ conformations ${ }^{21}$ in complexes 3, 5 and 6 (Table S1 $\dagger$ ). Bond lengths along the metallacycle are found to be comparable in $\mathrm{Ir}-\left(\kappa^{2}-\mathrm{NSi}^{\mathrm{Me} 2}\right)^{13}$ and $\mathrm{Ir}-\left(\kappa^{2}-\right.$ $\mathrm{NSi}^{\mathrm{iPr} 2}$ ) species (Table $\left.\mathrm{S} 2 \dagger\right)$. Comparison of bond lengths along the metallacycle with $\mathrm{N}-\mathrm{C}$ and $\mathrm{C}-\mathrm{O}$ bond lengths in 2-hydroxypiridinium, reveals a good agreement in $\mathrm{N}-\mathrm{C}$ bond lengths in the range 1.343(6)-1.367(5) $\AA$, vs. 1.344(2) $\AA$ in 2-hydroxypyridinium 2,4,6-trinitrophenolate ${ }^{22}$ and 1.364(6) and 1.367(7) $\AA$ for 2-hydroxypyridinium tris(2-hydroxypyridine)triiodide, ${ }^{23}$ while the slightly longer $\mathrm{C}-\mathrm{O}$ bond lengths observed in $\mathrm{Ir}-\left(\kappa^{2}-\mathrm{NSi}^{\mathrm{R} 2}\right)$ complexes may be attributed to the coordination of oxygen to the silicon atom. It is noteworthy that $\mathrm{O}-\mathrm{Si}$ bond lengths (between 1.719(3) and 1.734(3) ^) are longer than typical single O-Si bond (1.64 $\AA$ ), and that those found in rhodium complexes with ( $\mathrm{SiEt}_{2} \mathrm{Oadduct}$ ) ligands (Si-O between 1.626(9) and 
1.663(2) A limits). ${ }^{24}$ Accordingly, the metallacycle bond lengths found in $\mathrm{Ir}-\mathrm{NSi}^{\mathrm{iPr} 2}$ complexes are consistent with 2-pyridonestabilized silylene (I in Fig. 2).

The Ir-Si bond lengths found for complexes 3, 5 and $\mathbf{6}$, in the 2.2498(8)-2.2747(14) ^ range, compare well with the Ir-Si bond distances found for Ir-NSi ${ }^{\mathrm{Me} 2}$ species (Table 2), and are shorter than the Ir-Si bond distances reported for Ir-silyl bonds in the related $\mathrm{Ir}-\mathrm{PSi}^{\mathrm{Me} 2}$ complex $\left[\operatorname{IrCl}\left(\kappa^{2}-\mathrm{PSi}^{\mathrm{Me} 2}\right)\right]\left(\mathrm{PSi}^{\mathrm{Me} 2}\right.$ $\left.=\mathrm{PPh}_{2} \mathrm{CH}_{2} \mathrm{CH}_{2} \mathrm{SiMe}_{2}\right)(2.302(7)$ and $2.315(8) \AA) .{ }^{19}$ This suggests a base-stabilized silylene character for these Ir-Si bonds.

The geometry around the silicon atoms (sum of the angles between $\mathrm{Si}-\mathrm{C}$ and $\mathrm{Si}-\mathrm{Ir}$ bonds) may be used to distinguish between tetrahedral $\left(329^{\circ}\right)$ or trigonal $\left(360^{\circ}\right)$ geometries. In complexes 3, 5 and $\mathbf{6}$, values between $343.3(4)^{\circ}$ and 346.35 $(16)^{\circ}$ are observed for the sum of these angles. These values, as well as those found in $\operatorname{Ir}-\mathrm{NSS}^{\mathrm{R} 2}(\mathrm{R}=t \mathrm{Bu}, \mathrm{Me})$ species (Table S3 $\dagger$ ) are very close to the intermediate value between tetrahedral and trigonal arrangements $\left(344.5^{\circ}\right)$.

\section{Theoretical study of the nature of the Ir-Si bond in different iridium(III) complexes}

The short Ir-Si bond distances (2.25-2.28 $⿱$ ) together with the long $\mathrm{Si}-\mathrm{O}$ bond distances (around $1.73 \AA$ ) found for $\mathrm{Ir}-\mathrm{\kappa}^{2}-\mathrm{NSi}^{\mathrm{R} 2}$ $\left(\mathrm{R}=\mathrm{Me},{ }^{13} t \mathrm{Bu},{ }^{14} \mathrm{iPr}\right)$ complexes suggest some degree of silylene character for the Ir-Si bond between the iridium atom and the silicon atom in the coordinated $\mathrm{NSi}^{\mathrm{R} 2}$ ligands. Additionally, ${ }^{1} \mathrm{H}$ NMR studies show that such Ir-Si bonds are stable during $\mathrm{Ir}-\mathrm{\kappa}^{2}-\mathrm{NSi}^{\mathrm{R} 2}$-catalyzed $\mathrm{CO}_{2}{ }^{13}$ and formamide ${ }^{14}$ hydrosilylation processes, which further support that the strength of such iridium-silicon bonds is higher than that of iridium-silyl bonds present in the intermediates proposed for the aforementioned hydrosilylation processes. ${ }^{13 a}$ To shed light on the electronic structure of these bonds we have performed theoretical calculations on a set of complexes presenting different Ir-Si bonding patterns. As a representative example of iridium-silylene, the cationic complex $\left[(\mathrm{PNP})(\mathrm{H}) \mathrm{Ir}=\mathrm{SiPh}_{2}\right]^{+}$ $(\mathbf{B})^{2 i}$ has been considered. Complexes $\left[\operatorname{IrH}_{2}\left\{\mathrm{Si}(\mathrm{OTf}) \mathrm{Ph}_{2}\right\}(\mathrm{TFB})\right.$ $\left.\left(\mathrm{P}^{\mathrm{i}} \mathrm{Pr}_{3}\right)\right](\mathbf{C})^{4}$ and $\left[\operatorname{IrCp}^{*} \mathrm{Me}\left\{\mathrm{SiMe}_{2}(\text { pyridine })\right\}\left(\mathrm{PMe}_{3}\right)\right]^{+}(\mathbf{D})^{17}$ with an anionic base and a neutral base, respectively, have been chosen as examples of base-assisted Ir-silylenes. Finally, compound $\left[\mathrm{IrH}_{2}\left(\mathrm{SiEt}_{3}\right)(\mathrm{cod})\left(\mathrm{AsPh}_{3}\right)\right]^{25}$ (E) has been studied as an example of an iridium-silyl complex (Scheme 4). The DFT optimized equilibrium distances between the $\mathrm{Ir}$ and $\mathrm{Si}$ atoms found for complexes A-E and derived properties, such as NBO

Table 2 Ir-Si bond lengths $(\AA)$ for $\operatorname{Ir}-\mathrm{NSi}^{\mathrm{R} 2}(\mathrm{R}=t \mathrm{Bu}, \mathrm{Me}$, iPr) complexes

\begin{tabular}{lll}
\hline Complex & $\operatorname{Ir}-\mathrm{Si}(\AA)$ & Ref. \\
\hline$\left[\operatorname{Ir}(\mu-\mathrm{Cl})\left(\kappa^{2}-\mathrm{NSi}^{\mathrm{Me} 2}\right)_{2}\right]_{2}$ & $2.2634(14) ; 2.2695(14)$ & $13 a$ \\
{$\left[\mathrm{Ir}\left(\mathrm{CF}_{3} \mathrm{CO}_{2}\right)\left(\kappa^{2}-\mathrm{NSi}^{\mathrm{Me} 2}\right)_{2}\right]$} & $2.2552(14) ; 2.2747(14)$ & \\
{$\left[\mathrm{Ir}\left(\mu-\mathrm{CF}_{3} \mathrm{SO}_{3}\right)\left(\kappa^{2}-\mathrm{NSi}^{\mathrm{Me} 2}\right)_{2}\right]_{2}$} & $2.2545(10) ; 2.2505(11)$ & $13 a$ \\
{$\left[\operatorname{Ir}(\mathrm{Cl})\left(\kappa^{2}-\mathrm{NSi}^{\mathrm{iPr} 2}\right)_{2}\right], 3$} & $2.2700(7) ; 2.2499(7)$ molecule 1 & This work \\
& $2.2515(7) ; 2.2579(7)$ molecule 2 & \\
{$\left[\operatorname{Ir}\left(\mathrm{CF}_{3} \mathrm{CO}_{2}\right)\left(\kappa^{2}-\mathrm{NSi}^{\mathrm{iPr} 2}\right)_{2}\right], 5$} & $2.2702(10) ; 2.2668(11)$ & This work \\
{$\left[\operatorname{Ir}\left(\mathrm{CF}_{3} \mathrm{SO}_{3}\right)\left(\kappa^{2}-\mathrm{NSi}^{i \mathrm{Pr} 2}\right)_{2}\right], 6$} & $2.2573(8) ; 2.2498(8)$ & This work \\
{$\left[\operatorname{Ir}(\mathrm{H})\left(\mathrm{Cl}^{2}\right)\left(\kappa^{2}-\mathrm{NSi}^{\mathrm{Bu} 2}\right)(\mathrm{coe})\right]$} & $2.2853(6)$ & 14
\end{tabular}
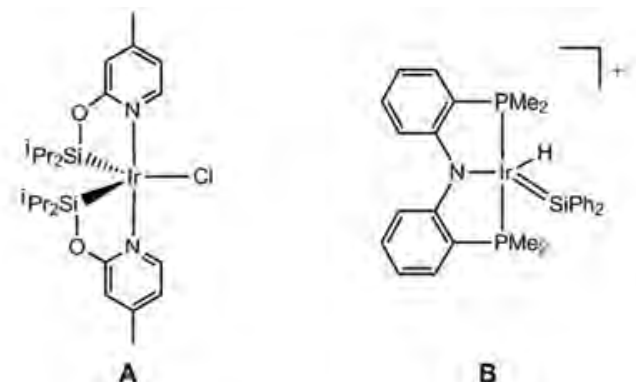

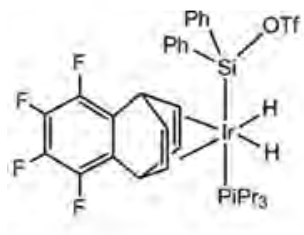

C

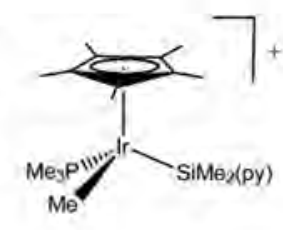

D

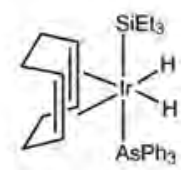

E
Scheme 4 Examples of different Ir-Si bonds: this work (A), silylene (B), base-assisted silylene (anionic base C; neutral base, D), and silyl (E).

atomic charges and QTAIM topological analysis, have been calculated (Table 3).

As expected, the Ir-silylene bond (complex B) presents the shortest bond distance $2.207 \AA$ while the longest one corresponds to Ir-silyl bond (complex E), $2.438 \AA$ A. Atomic charges shows systematically negative values at the Ir atom (from -0.572 to -0.800 ), which is consistent with its electron-rich character. In addition, high positive values at the $\mathrm{Si}$ atom (from +1.773 to +1.461 e) were found, which agrees with its poor electroattractor character. The calculated Wiberg bond order (WBI) indices are smaller than the expected bond order values, 0.990 and 0.608 for a formal double (complex B) and single bond (complex E), respectively. The anionic base assisted Ir-silylene bond in C show a WBI value of 0.589 even smaller than the Ir-silyl bond. Therefore, WBI values are inconsistent and cannot be used to characterize the bond order in the species under consideration.

The topological analysis of the electron density allows for a consistent analysis of all five complexes. A $(3,-1)$ bond critical point (bcp) connecting the Ir and Si basins through a bond path is found for all complexes. This bcp is located closer to the silicon than to the iridium with $\mathrm{d} r_{\mathrm{c}}(\mathrm{Si})$ values between $0.34-0.35$ (Table 3). The values of electron density, $\rho\left(r_{\mathrm{c}}\right)$, at the bcp decreases when moving from silylene $(0.1108$; B $)>$ baseassisted silylene (0.0961 and 0.1040 , for $\mathbf{C}$ and $\mathbf{D}$, respectively) $>$ silyl $\left(0.0836\right.$; E). Interestingly, A presents a $\rho\left(r_{\mathrm{c}}\right)$ of 0.1037 , which is a value very close to the obtained $(0.1040)$ for the neutral base-stabilized Ir-silylene D. Positive values of the Laplacian of electron density at the bcp indicates that charge is locally depleted and, then, corresponds to "closed shell" (donor-acceptor or van der Waals) interactions while negative values reveal local accumulations of charge, characteristic of covalent interactions. The calculated values show positive Laplacian signs for complexes A (0.0483) and B (0.0845) 
Table 3 DFT calculated properties for the Ir-Si bond in complexes A-D: Ir-Si equilibrium bond lengths (in Å), NBO atomic charges at Ir and Si atoms, Wiberg bond order (WBI) and results of the topological analysis of the electron density distribution: density, $\rho\left(r_{\mathrm{c}}\right)$, Laplacian, $\nabla^{2} \rho\left(r_{\mathrm{c}}\right)$, ellipticity, $\varepsilon_{c}$, total energy density, $H\left(r_{\mathrm{c}}\right)$ and position of the bcp to the $\mathrm{Si}$ atom $\mathrm{d} r_{\mathrm{c}}(\mathrm{Si})$ calculated as $\left(r_{\mathrm{c}}-\mathrm{Si}\right) /(\mathrm{Si}-\mathrm{Ir})$

\begin{tabular}{|c|c|c|c|c|c|c|c|c|c|}
\hline & $d(\mathrm{Ir}-\mathrm{Si})$ & $q(\mathrm{Ir})$ & $q(\mathrm{Si})$ & WBI & $\rho\left(r_{\mathrm{c}}\right)$ & $\nabla^{2} \rho\left(r_{\mathrm{c}}\right)$ & $\varepsilon_{\mathrm{c}}$ & $H\left(r_{\mathrm{c}}\right)$ & $\mathrm{d} r_{\mathrm{c}}(\mathrm{Si})$ \\
\hline B & 2.207 & -0.800 & 1.554 & 0.990 & 0.1108 & 0.0845 & 0.1736 & -0.0750 & 0.347 \\
\hline D & 2.316 & -0.451 & 1.470 & 0.739 & 0.1040 & -0.0717 & 0.0450 & -0.0733 & 0.352 \\
\hline $\mathbf{E}$ & 2.438 & -0.703 & 1.461 & 0.608 & 0.0836 & -0.0711 & 0.0057 & -0.0541 & 0.351 \\
\hline
\end{tabular}

suggesting a donor-acceptor interaction type while the values are negative for complexes $\mathbf{C}(-0.1020), \mathbf{D}(-0.717)$ and $\mathbf{E}$ $(-0.0711)$ indicating a more covalent nature for the base-stabilized silylene bond in $\mathbf{C}$ and $\mathbf{D}$ and the silyl bond in $\mathbf{E}$. The total energy density, $H\left(r_{\mathrm{c}}\right)$, at bcp shows negative values (typical of shared-electron interactions) but quantities are very small (characteristic of closed shell interactions) ${ }^{26,27}$ and they are very similar for all complexes.

The ellipticity at the bcp, $\varepsilon_{\mathrm{c}}=\left|\lambda_{1}\right| /\left|\lambda_{2}\right|-1$, is a function of the ratio of the rate of electron density decrease in the two directions perpendicular to the bond path at the bond critical point and it can be considered as a measure of the anisotropy of the electron density at the bcp. ${ }^{28}$ The largest value (0.1736) corresponds to the Ir-silylene and it is almost negligible (0.0057) for Ir-silyl bond. For the base-stabilized Ir-silylene bond in $\mathbf{C}$ and $\mathbf{D}$ the ellipticity is 0.0506 and 0.0450 , respectively, and increases to 0.0963 for complex A. These values are small in comparison to the ellipticity value obtained for a highly anisotropic bond such as the $\mathrm{C}=\mathrm{C}$ bond of ethene $\left(\varepsilon_{\mathrm{c}}=\right.$ 0.7023 at the same computational level). Therefore, the outcomes of these QTAIM studies show that the Ir-Si bond in A, as model of $\mathbf{3}$, presents a character intermediate between basestabilized Ir-silylene and Ir-silyl bonds.

\section{Conclusions}

In this work, new Ir-Si complexes $\left[\operatorname{Ir}(\mathrm{X})\left(\kappa^{2}-\mathrm{NSi}^{\mathrm{iPr} 2}\right)_{2}\right]\left(\mathrm{NSi}^{\mathrm{iPr} 2}=\right.$ (4-methyl-pyridine-2-yloxy)diisopropylsilyl; $\mathrm{X}=\mathrm{Cl}, \mathrm{CF}_{3} \mathrm{CO}_{2}$, $\mathrm{CF}_{3} \mathrm{SO}_{3}$ ) have been synthesized and characterized. The presence of isopropyl substituents at the silicon atoms of the $\mathrm{NSi}^{\mathrm{iPr} 2}$ ligands allows the formation of monomeric structures. In the above mentioned Ir-NSi ${ }^{\text {iPr2 }}$ complexes, the Ir-Si bond distances found by X-ray diffraction studies are in the range of 2.25-2.28 $\AA$, which is rather short for an Ir-silyl single bond. Moreover, long Si-O bond distances (around $1.73 \AA$ ) have also been found.

To further study the nature of the Ir-Si chemical bond in such species, a theoretical analysis using the QTAIM methodology on DFT calculated electron density has been performed. Due to the lack of Ir-Si bonds analyzed in the literature, other four existing complexes reported as representative examples of Ir-silylene, base assisted Ir-silylene (both with an anionic base and with a neutral base) and Ir-silyl bonds have also been considered in this study. The obtained results show that the Ir-Si bond in iridium(III)-NSi ${ }^{\mathrm{iPr} 2}$ species is intermediate between a base-stabilized Ir-silylene and Ir-silyl bonds. Thus, these bonds could be considered as 2-pyridone-stabilized iridium silylene/silyl bonds.

The strength of the Ir-Si bonds found in 2-pyridone-stabilized iridium-silylene/silyl complexes, which has been previously demonstrated in catalytic studies, makes them promising species as catalysts for hydrosilylation reactions. The study of the electronic effects introduced by the stabilized Ir-Si bonds in these species, which may lead to new catalytic applications, is in progress.

\section{Experimental section}

\section{General information}

All reactions and manipulations were carried out under an argon atmosphere by using Schlenk-type techniques or in a Glovebox-MBraun UNIlab. Organic solvents were dried by standard procedures and distilled under argon prior to use or obtained oxygen- and water-free from a Solvent Purification System (Innovative Technologies). ${ }^{1} \mathrm{H},{ }^{13} \mathrm{C},{ }^{29} \mathrm{Si}$ and ${ }^{19} \mathrm{~F}$ NMR spectra were obtained on a Bruker AV-300, AV-400 or AV-500 spectrometer using TMS as the internal reference. All chemical shifts $(\delta)$ are reported in ppm and coupling constants $(J)$ are reported in $\mathrm{Hz}$ to apparent peak multiplications. ${ }^{1} \mathrm{H}-{ }^{1} \mathrm{H}-\mathrm{COSY}$, ${ }^{13} \mathrm{C}-\mathrm{APT},{ }^{1} \mathrm{H} /{ }^{13} \mathrm{C}$ HSQC, ${ }^{1} \mathrm{H} /{ }^{13} \mathrm{C}$ HMBC and ${ }^{1} \mathrm{H} /{ }^{29} \mathrm{Si} \mathrm{HMBC}$ sequences were used for help in the assignments of the ${ }^{1} \mathrm{H}$ and ${ }^{13} \mathrm{C}\left\{{ }^{1} \mathrm{H}\right\}$ spectra.

\section{Synthesis of 4-methylpyridine-2-yloxydiisopropylsilane, $\mathrm{NSi}^{\mathrm{iPr} 2}-\mathrm{H}(1)$}

A THF solution $(10 \mathrm{~mL})$ of $\mathrm{HSiCl}^{\mathrm{i}} \mathrm{Pr}_{2}(1.10 \mathrm{~mL}, 6.50 \mathrm{mmol})$ was slowly added to a solution of 2-hydroxy-4-methyl-pyridine $(0.750 \mathrm{~g}, 6.90 \mathrm{mmol})$ and triethylamine $(3.80 \mathrm{~mL}, 27.60 \mathrm{mmol})$ in THF $(15 \mathrm{~mL})$ at $273 \mathrm{~K}$. After the addition the mixture was warmed to room temperature and stirred for $20 \mathrm{~h}$. The solvent was removed under reduced pressure and the product was extracted with hexane $(3 \times 15 \mathrm{~mL})$. Removal of the solvent gives a yellow oil, which was used without further purifications. Yield: $1.34 \mathrm{mg}$ (86\%). ${ }^{1} \mathrm{H}$ NMR (300 MHz, $\left.\mathrm{CD}_{2} \mathrm{Cl}_{2}, 298 \mathrm{~K}\right): \delta$ $7.96\left(\mathrm{~d}, 1 \mathrm{H}, \mathrm{py}, J_{\mathrm{H}-\mathrm{H}}=6.2 \mathrm{~Hz}\right), 6.74(\mathrm{~m}, 1 \mathrm{H}, \mathrm{py}), 6.58(\mathrm{~m}, 1 \mathrm{H}$, py), $4.54\left(\mathrm{t}, 1 \mathrm{H}, \mathrm{Si}-\mathrm{H},{ }^{3} \mathrm{~J}_{\mathrm{H}-\mathrm{H}}=2.1 \mathrm{~Hz}\right), 2.30\left(\mathrm{~s}, 3 \mathrm{H}, \mathrm{CH}_{3}-\mathrm{py}\right)$, $1.31\left(\mathrm{~m}, 2 \mathrm{H}, \mathrm{CH}^{-}{ }^{\mathrm{i}} \mathrm{Pr}\right), 1.12\left(\mathrm{~d}, 6 \mathrm{H}, J_{\mathrm{H}-\mathrm{H}}=6.2 \mathrm{~Hz}, \mathrm{CH}_{3}{ }^{-}{ }^{\mathrm{i}} \mathrm{Pr}\right), 1.10$ (d, $\left.6 \mathrm{H}, J_{\mathrm{H}-\mathrm{H}}=6.2 \mathrm{~Hz}, \mathrm{CH}_{3}-\mathrm{iPr}\right) .{ }^{13} \mathrm{C}\left\{{ }^{1} \mathrm{H}\right\}$ NMR plus APT plus 
HSQC ${ }^{1} \mathrm{H}^{-13} \mathrm{C}\left(75 \mathrm{MHz}, \mathrm{CD}_{2} \mathrm{Cl}_{2}, 298 \mathrm{~K}\right): \delta 163.3$ (s, $\left.C_{\text {ipso }}-\mathrm{py}\right)$, 151.1 (s, $C_{\text {ipso }}$-py), 147.2 (s, py), 119.0 (s, py), 112.9 (s, py), 21.1 (s, $\mathrm{CH}_{3}-\mathrm{py}$ ), 17.8 (s, $\mathrm{CH}_{3}-{ }^{\mathrm{i}} \mathrm{Pr}$ ), 17.7 (s, $\mathrm{CH}_{3}{ }^{\mathrm{i}} \mathrm{Pr}$ ), 12.8 (s, $\left.\mathrm{CH}-{ }^{\mathrm{i}} \mathrm{Pr}\right) .{ }^{29} \mathrm{Si}\left\{{ }^{1} \mathrm{H}\right\}$ NMR plus HMBC ${ }^{29} \mathrm{Si}^{-1} \mathrm{H},\left(298 \mathrm{~K}, \mathrm{CD}_{2} \mathrm{Cl}_{2}\right)$ : $\delta \quad 12.4$ ppm. High resolution mass spectrometry $\left(\mathrm{ESI}^{+}\right)$: calc. $m / z=222.1392$; found $m / z=222.1327\left(\mathbf{M}^{+}-\mathbf{H}\right)$.

\section{Synthesis of $\left[\operatorname{Ir}(\mathrm{Cl})\left(\kappa^{2}-\mathrm{NSi}^{\mathrm{iPr} 2}\right)_{2}\right](3)$}

Compound $1(0.500 \mathrm{~g}, 2.232 \mathrm{mmol})$ was slowly added to a suspension of $\left[\operatorname{Ir}(\mu-\mathrm{Cl})(\text { coe })_{2}\right]_{2}(0.500 \mathrm{~g}, 0.558 \mathrm{mmol})$ in $\mathrm{CH}_{2} \mathrm{Cl}_{2}$ $(15 \mathrm{~mL})$ at $273 \mathrm{~K}$ and the resulting mixture was stirred at room temperature for $48 \mathrm{~h}$. The solvent was removed in vacuo and the residue was washed with cooled hexane $(2 \times 10 \mathrm{~mL})$ to afford a white solid. Yield: $0.526 \mathrm{~g}$ (70\%). Anal. calcd for $\mathrm{C}_{24} \mathrm{H}_{40} \mathrm{ClIrN}_{2} \mathrm{O}_{2} \mathrm{Si}_{2}$ : C, 42.87; H, 6.00; N, 4.17. Found: C, 43.20; $\mathrm{H}, 5.99 ; \mathrm{N}, 4.24 .{ }^{1} \mathrm{H} \mathrm{NMR}\left(300 \mathrm{MHz}, \mathrm{CD}_{2} \mathrm{Cl}_{2}, 298 \mathrm{~K}\right): \delta 8.81$ (d, $\left.2 \mathrm{H}, J_{\mathrm{H}-\mathrm{H}}=6.3 \mathrm{~Hz}, 2 \mathrm{H}, \mathrm{py}\right), 6.71(\mathrm{~m}, 2 \mathrm{H}, \mathrm{py}), 6.63\left(\mathrm{ddd}, J_{\mathrm{HH}}=\right.$ 6.3; 1.9 and $0.6 \mathrm{~Hz}, 2 \mathrm{H}$, py), 2.27 (s, 6H, $\mathrm{CH}_{3}-\mathrm{py}$ ), 1.45 (septet, $2 \mathrm{H}, J_{\mathrm{H}-\mathrm{H}}=7.5 \mathrm{~Hz}, \mathrm{CH}^{\mathrm{i}} \mathrm{Pr}$ ), 1.22 (septet, $2 \mathrm{H}, J_{\mathrm{H}-\mathrm{H}}=7.3 \mathrm{~Hz}$, $\left.\mathrm{CH}-{ }^{\mathrm{i}} \mathrm{Pr}\right), 1.11$ (d, 6H, $\left.\mathrm{CH}_{3}{ }^{-}{ }^{\mathrm{i}} \mathrm{Pr}, J_{\mathrm{H}-\mathrm{H}}=7.5 \mathrm{~Hz}\right), 0.97$ (d, 6H, $\left.\mathrm{CH}_{3}{ }^{-}{ }^{\mathrm{i}} \mathrm{Pr}, J_{\mathrm{H}-\mathrm{H}}=7.3 \mathrm{~Hz}\right), 0.78\left(\mathrm{~d}, 6 \mathrm{H}, \mathrm{CH}_{3}{ }^{\mathrm{i}} \mathrm{Pr}, J_{\mathrm{H}-\mathrm{H}}=7.3 \mathrm{~Hz}\right)$, $0.54\left(\mathrm{~d}, 6 \mathrm{H}, \mathrm{CH}_{3}-\mathrm{iPr}, J_{\mathrm{H}-\mathrm{H}}=7.5 \mathrm{~Hz}\right) ;{ }^{13} \mathrm{C}\left\{{ }^{1} \mathrm{H}\right\}$ NMR plus APT plus HSQC ${ }^{1} \mathrm{H}^{-}{ }^{13} \mathrm{C}\left(75 \mathrm{MHz}, \mathrm{CD}_{2} \mathrm{Cl}_{2}, 298 \mathrm{~K}\right): \delta 169.8\left(\mathrm{~s}, C_{\text {ipso }}{ }^{-}\right.$ py), 152.8 (s, $C_{\text {ipso }}-$ py), 150.6 (s, py), 118.1 (s, py), 111.4 (s, py), 21.5 (s, $\mathrm{CH}_{3}$-py), 20.0 (s, $\mathrm{CH}_{3}-\mathrm{PPr}$ ), 19.2 (s, $\mathrm{CH}_{3}-\mathrm{iPr}$ ), 17.9 (s, $\mathrm{CH}-\mathrm{iPr}$ ), 17.3 (s, $\mathrm{CH}_{3}-{ }^{\mathrm{i}} \mathrm{Pr}$ ), 17.3 (s, $\left.\mathrm{CH}_{3}-{ }^{\mathrm{i}} \mathrm{Pr}\right), 16.9$ (s, CH- ${ }^{\mathrm{i}} \mathrm{Pr}$ ); ${ }^{29} \mathrm{Si}\left\{{ }^{1} \mathrm{H}\right\}$ NMR plus HMBC ${ }^{29} \mathrm{Si}^{-}{ }^{1} \mathrm{H}\left(298 \mathrm{~K}, \mathrm{CD}_{2} \mathrm{Cl}_{2}\right): \delta 50.5 \mathrm{ppm}$. High resolution mass spectrometry $\left(\mathrm{ESI}^{+}\right)$: calc. $\mathrm{m} / \mathrm{z}=$ 637.2258; found $\mathrm{m} / \mathrm{z}=637.2260\left(\mathrm{M}^{+}-\mathrm{Cl}\right)$.

\section{Synthesis $\left[\operatorname{Ir}\left(\mathrm{CF}_{3} \mathrm{CO}_{2}\right)\left(\kappa^{2}-\mathrm{NSi}^{\mathrm{iPr} 2}\right)_{2}\right](5)$}

Toluene $(15 \mathrm{~mL})$ was added to a light protected Schlenk tube containing a mixture of complex $3(0.125 \mathrm{~g}, 0.186 \mathrm{mmol})$ and silver trifluoroacetate $(0.045 \mathrm{~g}, 0.204 \mathrm{mmol})$. The resulting suspension was stirred at room temperature for $24 \mathrm{~h}$ and filtered out through Celite. The solvent was removed in vacuo and the residue extracted with pentane $(3 \times 5 \mathrm{~mL})$ to afford a white solid. Yield $0.106 \mathrm{~g}$ (76\%). Anal. calcd for $\mathrm{C}_{26} \mathrm{H}_{40} \mathrm{~F}_{3} \mathrm{IrN}_{2} \mathrm{O}_{4} \mathrm{Si}_{2}$ : $\mathrm{C}, 41.64 ; \mathrm{H}, 5.38 ; \mathrm{N}, 3.74$. Found: $\mathrm{C}, 42.01 ; \mathrm{H}, 5.71 ; \mathrm{N}, 3.78 .{ }^{1} \mathrm{H}$ NMR (300 MHz, $\left.\mathrm{C}_{6} \mathrm{D}_{6}, 298 \mathrm{~K}\right): \delta 8.41\left(\mathrm{~d}, 2 \mathrm{H}, J_{\mathrm{H}-\mathrm{H}}=6.3 \mathrm{~Hz}, 2 \mathrm{H}\right.$, py), 6.40 (brs, 2H, py), $5.82\left(\mathrm{dd}, 2 \mathrm{H}, J_{\mathrm{H}-\mathrm{H}}=6.3\right.$ and $\left.1.8 \mathrm{~Hz}, \mathrm{py}\right)$, 1.82 (septet, $2 \mathrm{H}, J_{\mathrm{H}-\mathrm{H}}=7.5 \mathrm{~Hz}, \mathrm{CH}-\mathrm{iPr}$ ), $1.52\left(\mathrm{~m}, 2 \mathrm{H}, J_{\mathrm{H}-\mathrm{H}}=7.3\right.$ $\mathrm{Hz}, \mathrm{CH}-\mathrm{iPr}$ ), 1.51 (s, 6H, $\left.\mathrm{CH}_{3}-\mathrm{py}\right), 1.33$ (d, 6H, $J_{\mathrm{H}-\mathrm{H}}=7.5 \mathrm{~Hz}$, $\mathrm{CH}_{3}-\mathrm{PPr}$ ), 1.29 (d, 6H, $J_{\mathrm{H}-\mathrm{H}}=7.3 \mathrm{~Hz}, \mathrm{CH}_{3}-\mathrm{PPr}$ ), 1.14 (d, 6H, $\left.J_{\mathrm{H}-\mathrm{H}}=7.3 \mathrm{~Hz}, \mathrm{CH}_{3}-\mathrm{PPr}\right), 0.72\left(\mathrm{~m}, 6 \mathrm{H},\left(\mathrm{d}, 6 \mathrm{H}, J_{\mathrm{H}-\mathrm{H}}=7.5 \mathrm{~Hz}\right.\right.$, $\left.\mathrm{CH}_{3}-\mathrm{iPr}\right) .{ }^{13} \mathrm{C}\left\{{ }^{1} \mathrm{H}\right\}$ NMR plus APT plus HSQC (75 MHz, $\left.\mathrm{C}_{6} \mathrm{D}_{6}\right): \delta$

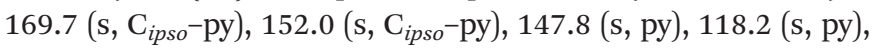
111.6 (s, py), 20.5 (s, $\mathrm{CH}_{3}-\mathrm{py}$ ), 19.5, 18.5, 17.7 and 17.6 (s, $\mathrm{CH}_{3}-\mathrm{iPr}$ ), 17.0 and 16.7 (s, CH-iPr). ${ }^{19} \mathrm{~F}\left\{{ }^{1} \mathrm{H}\right\}$ NMR $(282 \mathrm{MHz}$, $\mathrm{C}_{6} \mathrm{D}_{6}, 298 \mathrm{~K}$ ): $\delta-74.62$ (s) ppm. ${ }^{29} \mathrm{Si}$ NMR plus HMBC ${ }^{29} \mathrm{Si}^{1}{ }^{1} \mathrm{H}$ (298 K): $\delta 42.2 \mathrm{ppm}$. High resolution mass spectrometry $\left(\mathrm{ESI}^{+}\right)$: calc. $m / z=637.2258$; found $m / z=637.2250\left(\mathbf{M}^{+}-\mathrm{CF}_{3} \mathrm{CO}_{2}\right)$.

\section{Synthesis $\left[\mathrm{Ir}\left(\mathrm{CF}_{3} \mathrm{SO}_{3}\right)\left(\kappa^{2}-\mathrm{NSi}^{\mathrm{iPr} 2}\right)_{2}\right](6)$}

$\mathrm{CH}_{2} \mathrm{Cl}_{2}(15 \mathrm{~mL})$ was added to a light protected Schlenk tube containing a mixture of complex $3(0.240 \mathrm{~g}, 0.356 \mathrm{mmol})$ and silver triflate $(0.110 \mathrm{~g}, 0.428 \mathrm{mmol})$. The resulting suspension was stirred at room temperature for $14 \mathrm{~h}$ and filtered out through Celite. The solvent was removed in vacuo and the residue washed with cooled $(273 \mathrm{~K})$ pentane $(3 \times 5 \mathrm{~mL})$ to afford a yellow solid. Yield $0.182 \mathrm{~g}(67 \%) .{ }^{1} \mathrm{H}$ NMR $(300 \mathrm{MHz}$, $\left.\mathrm{C}_{6} \mathrm{D}_{6}, 298 \mathrm{~K}\right): \delta 8.95\left(\mathrm{~d}, 2 \mathrm{H}, \mathrm{py}, J_{\mathrm{H}-\mathrm{H}}=6.3 \mathrm{~Hz}\right), 6.33(\mathrm{brs}, 2 \mathrm{H}$, py), 6.01 (dd, 2H, $J_{\mathrm{H}-\mathrm{H}}=6.3$ and $1.5 \mathrm{~Hz}$ py), 1.66 (septet, $2 \mathrm{H}$, $J_{\mathrm{H}-\mathrm{H}}=7.5, \mathrm{CH}^{-}{ }^{\mathrm{i}} \mathrm{Pr}$ ), 1.48 (s, $\mathrm{CH}_{3}-\mathrm{py}$ ), 1.38 (septet, $2 \mathrm{H}, J_{\mathrm{H}-\mathrm{H}}=$ 7.2, $\left.\mathrm{CH}^{-}{ }^{\mathrm{i}} \mathrm{Pr}\right), 1.24\left(\mathrm{~d}, 12 \mathrm{H}, J_{\mathrm{H}-\mathrm{H}}=7.5 \mathrm{~Hz}, \mathrm{CH}_{3}{ }^{-}{ }^{\mathrm{i}} \mathrm{Pr}\right), 1.08(\mathrm{~d}, 6 \mathrm{H}$, $\left.J_{\mathrm{H}-\mathrm{H}}=7.5 \mathrm{~Hz}, \mathrm{CH}_{3}-{ }^{\mathrm{i}} \mathrm{Pr}\right), 0.54\left(\mathrm{~d}, 6 \mathrm{H}, J_{\mathrm{H}-\mathrm{H}}=7.2 \mathrm{~Hz}, \mathrm{CH}_{3}-{ }^{\mathrm{i}} \mathrm{Pr}\right)$; ${ }^{13} \mathrm{C}\left\{{ }^{1} \mathrm{H}\right\}$ NMR plus APT plus HSQC ${ }^{1} \mathrm{H}^{13} \mathrm{C}\left(75 \mathrm{MHz}, \mathrm{C}_{6} \mathrm{D}_{6}\right.$, $298 \mathrm{~K}$ ): $\delta 169.0$ (s, $\left.C_{i p s o}-\mathrm{py}\right), 153.2$ (s, $\left.C_{i p s o}-\mathrm{py}\right), 149.5$ (s, py), 118.5 (s, py), 111.4 (s, py), 20.6 (s, $\left.\mathrm{CH}_{3}-\mathrm{py}\right), 19.7$ (s, $\mathrm{CH}_{3}{ }^{\mathrm{i}} \mathrm{Pr}$ ), 18.8 (s, $\mathrm{CH}_{3}-{ }^{\mathrm{i}} \mathrm{Pr}$ ), 17.6 (s, $\left.\mathrm{CH}_{3}-{ }^{\mathrm{i}} \mathrm{Pr}\right), 17.1$ (s, CH${ }^{\mathrm{i}} \mathrm{Pr}$ ), 17.0 (s, $\mathrm{CH}_{3}-{ }^{\mathrm{i}} \mathrm{Pr}$ ), 16.7 (s, CH- $\left.{ }^{\mathrm{i}} \mathrm{Pr}\right) ;{ }^{19} \mathrm{~F}\left\{{ }^{1} \mathrm{H}\right\} \mathrm{NMR}\left(282 \mathrm{MHz}, \mathrm{C}_{6} \mathrm{D}_{6}\right.$, $298 \mathrm{~K}) \delta-77.10$ (s) ppm; ${ }^{29} \mathrm{Si}\left\{{ }^{1} \mathrm{H}\right\}$ NMR plus HMBC ${ }^{29} \mathrm{Si}^{1}{ }^{1} \mathrm{H}$ (298 K): $\delta 44.5 \mathrm{ppm}$. High resolution mass spectrometry $\left(\mathrm{ESI}^{+}\right)$: calc. $m / z=637.2258$; found $m / z=637.2245\left(\mathrm{M}^{+}-\mathrm{CF}_{3} \mathrm{SO}_{3}\right)$.

\section{Crystal structure determination of complexes 3, 5 and 6}

Single crystal X-ray diffraction data were collected at 100(2) K with graphite-monochromated Mo K $\alpha$ radiation $(\lambda=0.71073 \AA)$ using narrow frame rotation $\left(\Delta \omega=0.3^{\circ}\right)$ on a Bruker APEX DUO (complexes 3 and 5) or Smart APEX (complex 6) diffractometers. Measured intensities were integrated and corrected for absorption effects with SAINT+ (ref. 29) and SADABS ${ }^{30}$ programs, included in APEX2 package. The structures were solved with direct methods with SHELXS- $2013^{31}$ and refined by full-matrix least-squares refinement on $F^{2}$ with SHELXL-2018 ${ }^{32}$ program, included in WingX package. ${ }^{33}$ CCDC 1989980-1989982 $\dagger$ contains the supplementary crystallographic data for this paper.

Crystal data compound 3. $\mathrm{C}_{24} \mathrm{H}_{40} \mathrm{ClIrN}_{2} \mathrm{O}_{2} \mathrm{Si}_{2}, M=672.41$; orange prism $0.103 \times 0.197 \times 0.203 \mathrm{~mm}^{3}$; triclinic $P \overline{1}, a=$ 12.0235(6), $b=14.4027(7), c=17.5331(8) \AA, \alpha=105.4291(7), \beta=$ 103.4935(6), $\gamma=94.0182(6)^{\circ}, V=2817.6(2) \AA^{3} ; Z=4 ; D_{\mathrm{c}}=$ $1.585 \mathrm{~g} \mathrm{~cm}^{-3} ; \mu=4.941 \mathrm{~mm}^{-1} ; T_{\min } / T_{\max }: 0.4155 / 0.5567$; $64840 / 15705$ reflections measured/unique $\left(R_{\mathrm{int}}=0.0240\right)$, number of data/restraint/parameters $15705 / 0 / 596, R_{1}\left(F^{2}\right)=$ 0.0247 (13 872 reflections, $I>2 \sigma(I)$ ) and $\mathrm{w} R\left(F^{2}\right)=0.0655$ (all

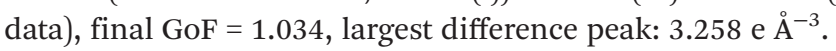

Crystal data compound 5. $\mathrm{C}_{26} \mathrm{H}_{40} \mathrm{~F}_{3} \mathrm{IrN}_{2} \mathrm{O}_{4} \mathrm{Si}_{2}, M=749.98$; white plate $0.080 \times 0.170 \times 0.180 \mathrm{~mm}^{3}$; triclinic $P \overline{1}, a=9.2857$ (5), $b=11.6094(6), c=14.7740(8) \AA, \alpha=91.0610(10)^{\circ}, \beta=$ $96.4680(10)^{\circ}, \gamma=104.4890(10)^{\circ}, V=1530.38(14) \AA^{3} ; Z=2 ; D_{\mathrm{c}}=$ $1.628 \mathrm{~g} \mathrm{~cm}^{-3} ; \mu=4.491 \mathrm{~mm}^{-1} ; T_{\min } / T_{\max }: 0.5243 / 0.7458$; $17768 / 7361$ reflections measured/unique $\left(R_{\text {int }}=0.0251\right)$, number of data/restraint/parameters 7361/0/351, $R_{1}\left(F^{2}\right)=$ 0.0313 (6783 reflections, $I>2 \sigma(I))$ and $\mathrm{w} R\left(F^{2}\right)=0.0734$ (all data), final $\mathrm{GoF}=1.044$, largest difference peak: $2.089 \mathrm{e} \AA^{-3}$. $\mathrm{CF}_{3}$ fragment has been found to be disordered. Fluorine atoms have been included in the model in two sets of positions with complementary occupancy factors $(0.529 / 0.471(8))$ and isotropically refined.

Crystal data compound 6. $\mathrm{C}_{25} \mathrm{H}_{40} \mathrm{~F}_{3} \mathrm{IrN}_{2} \mathrm{O}_{5} \mathrm{SSi}_{2}, M=786.03$; colourless plate $0.091 \times 0.200 \times 0.310 \mathrm{~mm}^{3}$; monoclinic $P 2_{1} / c$, 
$a=10.4264(6), b=16.6127(9), c=18.0892(10) \AA, ~ \beta=90.6090$ $(10)^{\circ}, \quad V=3133.1(3) \AA^{3} ; Z=4 ; \quad D_{\mathrm{c}}=1.666 \mathrm{~g} \mathrm{~cm} \mathrm{~cm}^{-3}$; $\mu=4.458 \mathrm{~mm}^{-1} ; T_{\min } / T_{\max }: 0.3767 / 0.5274 ; 36878 / 8700$ reflections measured/unique $\left(R_{\mathrm{int}}=0.0337\right)$, number of data/ restraint/parameters 8700/0/375, $R_{1}\left(F^{2}\right)=0.0268$ (7346 reflections, $I>2 \sigma(I))$ and $\mathrm{w} R\left(F^{2}\right)=0.0581$ (all data), final $\mathrm{GoF}=1.034$, largest difference peak: $1.819 \mathrm{e} \AA^{-3}$. Triflate ligand has been found to be disordered. It has been included in the model in two sets of positions with complementary occupancy factors $(0.771 / 0.229(2))$.

\section{Computational details}

DFT calculations were performed using the Gaussian09 software package, D.01 revision. ${ }^{34}$ The energies and gradient calculations were computed by using the B3LYP exchange-correlation functional, ${ }^{35}$ in conjunction with the D3BJ dispersion correction scheme developed by Grimme et al. ${ }^{36}$ We also set the "ultrafine" grid. The def2-SVP ${ }^{37}$ basis set was used for all the atoms in geometry optimization, and energies. QTAIM study was performed using the program AIMPAC. ${ }^{38}$

\section{Conflicts of interest}

There are no conflicts to declare.

\section{Acknowledgements}

The financial support from MINECO/FEDER project PGC2018099383-B-I00 and DGA/FSE project E42_20R is gratefully acknowledged. Authors would like to acknowledge the use of Servicio General de Apoyo a la Investigación-SAI at the Universidad de Zaragoza and at the ISQCH/CEQMA (CSIC).

\section{Notes and references}

1 For recent reviews see: (a) M. C. Lipke, A. L. LibermanMartin and T. D. Tilley, Angew. Chem., Int. Ed., 2017, 56, 2260-2294; (b) J. Y. Corey, Chem. Rev., 2016, 116, 1129111435; (c) R. Waterman, P. G. Hayes and T. D. Tilley, Acc. Chem. Res., 2007, 40, 712-719; (d) L. Álvarez-Rodríguez, J. A. Cabeza, P. García-Álvarez and D. Polo, Coord. Chem. Rev., 2015, 300, 1-28; (e) M. Okazaki, H. Tobita and H. Ogino, Dalton Trans., 2003, 493-506; $(f)$ J. Y. Corey and J. Braddock-Wilking, Chem. Rev., 1999, 99, 175-292.

2 For some examples see: (a) K. Riener, M. P. Högerl, P. Gigler and F. E. Kühn, ACS Catal., 2012, 2, 613-621; (b) P. Gigler, B. Bechlars, W. A. Herrmann and F. E. Kühn, J. Am. Chem. Soc., 2011, 133, 1589-1596; (c) T. Muraoka, Y. Shimizu, H. Kobayashi, K. Ueno and H. Ogino, Organometallics, 2010, 29, 5423-5426; (d) N. Schneider, M. Finger, C. Haferkemper, S. Bellemin-Laponnaz, P. Hofmann and L. H. Gade, Angew. Chem., Int. Ed., 2009, 48, 1609-1613; (e) N. Schneider, M. Finger, C. Haferkemper, S. Bellemin-Laponnaz, P. Hofmann and
L. H. Gade, Chem. - Eur. J., 2009, 15, 11515-11529; (f) P. B. Glaser and T. D. Tilley, J. Am. Chem. Soc., 2003, 125, 13640-13641; $(g)$ C. Beddie and M. B. A. Hall, J. Am. Chem. Soc., 2004, 126, 13564-13565; (h) E. Calimano and T. D. Tilley, J. Am. Chem. Soc., 2008, 130, 9226-9227; (i) E. Calimano and T. D. Tilley, J. Am. Chem. Soc., 2009, 131, 11161-11173.

3 (a) D. A. Straus, T. D. Tilley, A. L. Rheinglod and S. J. Geib, J. Am. Chem. Soc., 1987, 109, 5872-5873; (b) C. Zybill and G. Müller, Angew. Chem., Int. Ed. Engl., 1987, 26, 669-670.

4 W. Chen, A. J. Edwards, M. A. Esteruelas, F. J. Lahoz, M. Olivan and L. A. Oro, Organometallics, 1996, 15, 21852188.

5 (a) M. E. Fasulo, P. B. Glaser and T. D. Tilley, Organometallics, 2011, 30, 5524-5531; (b) J. D. Feldman, J. C. Peters and T. D. Tilley, Organometallics, 2002, 21, 4065-4075; (c) S. R. Klei, T. D. Tilley and R. G. Bergman, Organometallics, 2002, 21, 3376-3387; (d) J. C. Peters, J. D. Feldman and T. D. Tilley, J. Am. Chem. Soc., 1999, 121, 9871-9872.

6 (a) D. H. Binh, M. Hamdaoui, D. Fischer-Krauser, L. Karmazin, C. Bailly and J.-P. Djukic, Chem. - Eur. J., 2018, 24, 17577-17589; (b) J. A. Cabeza, P. García-Álvarez and L. González-Álvarez, Chem. Commun., 2017, 53, 1027510278.

7 H. Hashimoto, T. Suzuki and H. Tobita, Dalton Trans., 2010, 39, 9386-9400.

8 L. Ehrlich, R. Gericke, E. Brendler and J. Wagler, Inorganics, 2018, 6, 119, DOI: 10.3390/inorganics6040119.

9 J. M. Rawson and R. E. P. Winpenny, Coord. Chem. Rev., 1995, 139, 313-374.

10 (a) T. Sato, M. Okazaki and H. Tobita, Chem. Lett., 2004, 33, 868-869; (b) T. Sato, M. Okazaki, H. Tobita and H. Ogino, J. Organomet. Chem., 2003, 669, 189-199; (c) T. Sato, H. Tobita and H. Ogino, Chem. Lett., 2001, 30, 854-855; (d) H. Tobita, T. Sato, M. Okazaki and H. Ogino, J. Organomet. Chem., 2000, 611, 314-322.

11 W.-H. Kwok, G.-L. Lu, C. E. F. Rickard, W. R. Roper and L. J. Wright, J. Organomet. Chem., 2004, 689, 2979-2987.

12 Y. Kanno, T. Komuro and H. Tobita, Organometallics, 2015, 34, 3699-3705.

13 (a) J. Guzmán, P. García-Orduña, V. Polo, F. J. Lahoz, L. A. Oro and F. J. Fernández-Alvarez, Catal. Sci. Technol., 2019, 9, 2858-2867; (b) J. Guzmán, P. García-Orduña, F. J. Lahoz and F. J. Fernández-Alvarez, RSC Adv., 2020, 10, 9582-9586.

14 J. Guzmán, A. M. Bernal, P. García-Orduña, F. J. Lahoz, L. A. Oro and F. J. Fernández-Alvarez, Dalton Trans., 2019, 48, 4255-4262.

15 (a) G. Frenking and N. Frölich, Chem. Rev., 2000, 100, 717-774; (b) G. Frenking, M. Solà and S. F. Vyboishchikov, J. Organomet. Chem., 2005, 690, 6178-6204; (c) H. Jacobsen and T. Ziegler, Organometallics, 1995, 14, 224-230; (d) F. P. Arnold, Organometallics, 1999, 18, 48004809. 
16 J. Guzmán, A. Torguet, P. García-Orduña, F. J. Lahoz, L. A. Oro and F. J. Fernández-Alvarez, J. Organomet. Chem., 2019, 897, 50-56.

17 (a) S. R. Klei, T. D. Tilley and R. G. Bergman, Organometallics, 2001, 20, 3220-3222; (b) S. R. Klei, T. D. Tilley and R. G. Bergman, Organometallics, 2002, 21, 4648-4661.

18 M. K. Hays and R. Eisenberg, Inorg. Chem., 1991, 30, 26232630.

19 M. J. Auburn, R. D. Holmes-Smith, S. R. Stobart, P. K. Bakshi and T. S. Cameron, Organometallics, 1996, 15, 3032-3036.

20 M. Zhou, S. I. Johnson, Y. Gao, T. J. Emge, R. J. Nielsen, W. A. III Goddard and A. S. Goldman, Organometallics, 2015, 34, 2879-2888.

21 D. Cremer and J. A. Pople, J. Am. Chem. Soc., 1975, 97, 1354-1358.

22 V. Bertolasi, P. Gilli and G. Gilli, Cryst. Growth Des., 2011, 11, 2724-2735.

23 C. D. Antoniadis, S. K. Hadjikakou, N. Hadjiliadis, M. Kubicki and I. S. Butler, New J. Chem., 2005, 29, 714720.

24 C. Karmel, B. Li and J. F. Hartwig, J. Am. Chem. Soc., 2018, 140, 146-1470.

25 M. J. Fernández, M. A. Esteruelas, L. A. Oro, M.-C. Apreda, C. Foces-Foces and F. H. Cano, Organometallics, 1987, 6, 1751-1756.
26 D. Cremer and E. Kraka, Angew. Chem., Int. Ed. Engl., 1984, 23, 627-628.

27 E. Espinosa, I. Alkorta, J. Elguero and E. Molins, J. Chem. Phys., 2002, 117, 5529-5542.

28 R. F. W. Bader, Atoms in Molecules A Quantum Theory, Clarendon Press, 1994.

29 SAINT+, version 6.01: Area-Detector Integration Software, Bruker AXS, Madison, 2001.

30 (a) SADABS (Version 2016/02), Bruker AXS, Madison, 2016;

(b) L. Krause, R. Herbst-Irmer, G. M. Sheldrick and D. Stalke, J. Appl. Crystallogr., 2015, 48, 3-10.

31 (a) G. M. Sheldrick, Acta Crystallogr., Sect. A: Found. Crystallogr., 1990, 46, 467-473; (b) G. M. Sheldrick, Acta Crystallogr., Sect. A: Found. Crystallogr., 2008, 64, 112-122.

32 G. M. Sheldrick, Acta Crystallogr., Sect. C: Struct. Chem., 2015, 71, 3-8.

33 L. J. Farrugia, J. Appl. Crystallogr., 2012, 45, 849-854.

34 M. J. Frisch, et al., Gaussian 09, Revision D.01, Gaussian, Inc., Wallingford CT, 2009.

35 A. D. Becke, J. Chem. Phys., 1993, 98, 1372-1377.

36 (a) S. Grimme, J. Antony, S. Ehrlich and H. Krieg, J. Chem. Phys., 2010, 132, 154104; (b) E. R. Johnson and A. D. Becke, J. Chem. Phys., 2005, 123, 024101.

37 F. Weigend and R. Ahlrichs, Phys. Chem. Chem. Phys., 2005, 7, 3297-3305.

38 F. W. Biegler-könig, R. F. W. Bader and T.-H. Tang, J. Comput. Chem., 1982, 3, 317-328. 